\title{
Final Report: Molecular Basis for Microbial Adhesion and Geochemical Surface Reactions: A Study Across Scales DE-FG02-06ER15764
}

\section{June 2013}

\section{David A. Dixon, The University of Alabama}

Computational chemistry was used to help provide a molecular level description of the interactions of Gram-negative microbial membranes with subsurface materials. The goal is to develop a better understanding of the molecular processes involved in microbial metal binding, microbial attachment to mineral surfaces, and, eventually, oxidation/reduction reactions (electron transfer) that can occur at these surfaces and are mediated by the bacterial exterior surface. The project focused on the interaction of the outer microbial membrane, which is dominated by an exterior lipopolysaccharide (LPS) portion, of Pseudomonas aeruginosa with the mineral goethite and with solvated ions in the environment. This was originally a collaborative project with T.P. Straatsma and B. Lowery of the Pacific Northwest National Laboratory. The University of Alabama effort used electronic structure calculations to predict the molecular behavior of ions in solution and the behavior of the sugars which form a critical part of the LPS. The interactions of the sugars with metal ions are expected to dominate much of the microscopic structure and transport phenomena in the LPS. This work, in combination with the molecular dynamics simulations of Straatsma and the experimental electrochemistry and microscopy measurements of Lowry, both at PNNL, is providing new insights into the detailed molecular behavior of these membranes in geochemical environments.

The effort at The University of Alabama has three components: solvation energies and structures of ions in solution, prediction of the acidity of the critical groups in the sugars in the LPS, and binding of metal ions to the sugar anions. An important aspect of the structure of the LPS membrane as well as ion transport in the LPS is the ability of the sugar side groups such as the carboxylic acids and the phosphates to bind positively charged ions. We are studying the acidity of the acidic side groups in order to better understand the ability of these groups to bind metal ions. We need to understand the solvation properties of the metal ions in solution and their ability to bind not only to the sugars but to proteins and to other anions. Our goal is then to be able to predict the ability of the side groups to bind metal ions. One result from the earlier molecular dynamics simulations is the exclusion of water from the inner hydrophobic part of the membrane. We thus need to investigate the binding of the cations in media with different dielectric constants.

\section{Acid-base Biochemistry}

There is significant interest in the acidities of various biological groups and the subsequent ability of the anions to bind cations. The study of gas phase proton transfer reactions provides unique insights into the structures and energetics of such groups. We calculated the acidities of the common amino acids. The gas-phase acidities, where the gas phase acidity is the free energy $\Delta \mathrm{G}_{\text {acid }}$ for the reaction $\mathrm{AH} \rightarrow \mathrm{A}^{-}+\mathrm{H}^{+}$, of the $20 \mathrm{~L}$-amino acids have been predicted at the composite G3(MP2) level. A broad range of structures of the neutral and anion were studied to determine the lowest energy conformer. Excellent agreement is found with the available 
experimental gas-phase deprotonation enthalpies, and the calculated values are within experimental error. The results confirm the amino acid GA scale and can be used to substantially reduce the error bars for these values. In general, the proton is lost from the $-\mathrm{CO}_{2} \mathrm{H}$ acid group to form the $-\mathrm{CO}_{2}{ }^{-}$anionic group, except for cysteine where the proton is partially shared between the $\mathrm{S}^{-}$and $\mathrm{CO}_{2}{ }^{-}$groups and is closer to the sulfur. We confirm that the proton is lost from the $\mathrm{CO}_{2} \mathrm{H}$ group in tyrosine. Removal of a proton from the $-\mathrm{CO}_{2} \mathrm{H}$ group results in gas-phase acidities between 329 and $335 \mathrm{kcal} / \mathrm{mol}$ showing that substituent effects are not very large except for a conformer of arginine, asparagine, glutamine, the histidine $\pi$ tautomer, serine, and two conformers of threonine where strong hydrogen bonds form with the side chain groups leading to lower gas-phase acidities between 321 and $326 \mathrm{kcal} / \mathrm{mol}$. For aspartic acid and glutamic acid, the substituents lead to lower GA values ( $316 \mathrm{kcal} / \mathrm{mol}$ ). Self-consistent reaction field (SCRF) calculations with the COSMO parameterization were used to predict the $\mathrm{pK}_{\mathrm{a}}$ 's in aqueous solution. The differences in the $\mathrm{p} K_{\mathrm{a}}$ values from experiment were used to estimate the free energy difference between the zwitterion and non-zwitterion forms in solution. Asparagine, lysine, phenylalanine, proline, and tyrosine have the non-zwitterionic structure about $5 \mathrm{kcal} / \mathrm{mol}$ higher in free energy than the zwitterions, whereas the zwitterionic and nonzwitterionic forms of arginine are within better than $1 \mathrm{kcal} / \mathrm{mol}$ of each other. Heats of formation from the total atomization energies (TAEs) and isodesmic heats of formation of the common amino acids are within $4 \mathrm{kcal} / \mathrm{mol}$ of the available experimental values for the TAEs and within $2 \mathrm{kcal} / \mathrm{mol}$, except for proline and valine, for the isodemic reaction approach. The calculated heats of formation of the neutral compounds provide the first reliable set of these values in the gas phase. Further calculations were performed on 5 rare amino acids to predict their heats of formation, acidities, and $\mathrm{pK}_{\mathrm{a}}$ values. Details are provided in "Fundamental Thermochemical Properties of Amino Acids: Gas-Phase and Aqueous Acidities and Gas-Phase Heats of Formation,” M. L. Stover, V. E. Jackson, M. H. Matus, M. A. Adams, C. J. Cassady, and D. A. Dixon, J. Phys. Chem. B, 2012, 116, 2905-2916.

\section{Metal ion solvation and complexation}

A component of the study is to predict the solvation properties of metal ions in aqueous solution. As part of this effort, we predicted the solvation energies of ions in aqueous solution using a supermolecule-continuum solvation model developed in the group. The geometries for the metal cations $\mathrm{Be}^{2+}, \mathrm{Mg}^{2+}, \mathrm{Al}^{3+}, \mathrm{Ca}^{2+}, \mathrm{Mn}^{2+}, \mathrm{Fe}^{3+}, \mathrm{Fe}^{2+}, \mathrm{Co}^{2+}, \mathrm{Ni}^{2+}, \mathrm{Cu}^{2+}, \mathrm{Zn}^{2+}$ and $\mathrm{Sr}^{2+}$ with one solvation shell of water molecules. Additional single point calculations at the MP2 level were done with the aug-cc-pVnZ-PP basis sets $(n=D, T, Q)$ and associated ECPs on the transition metals and the appropriate Stuttgart basis set on $\mathrm{U}$ for $\mathrm{UO}_{2}{ }^{2+}$. The continuum model solvation calculations were done with the COSMO parameterization of the self consistent reaction field. The results (Table 5) show that there is good agreement for the +2 monoatomic ions with experiment if the proper solvation shell size is chosen for the first solvation shell. Thus, we can see that most of the ions prefer hexacoordination. However, the results for $\mathrm{Ca}^{2+}$ show that the solvation shell can basically fall anywhere from 6 to $8 \mathrm{H}_{2} \mathrm{O}$ molecules. In contrast, $\mathrm{pK}_{\mathrm{a}}\left(\mathrm{Sr}^{2+}\right)$ clearly is best fit for a first solvation shell of $7 \mathrm{H}_{2} \mathrm{O}$ molecules. The trications show substantial deviations in terms of the $\mathrm{pK}_{\mathrm{a}}$ if only a single solvation shell is chosen. The use of a second solvation shell dramatically improves the agreement with experiment for $\mathrm{Al}^{3+}$ and $\mathrm{Fe}^{3+}$. This suggests that there is a substantial amount of charge delocalized to the second solvation shell for the trications. We note that in most cases there is good qualitative agreement between the $\mathrm{pK}_{\mathrm{a}}$ 's 
calculated with DFT with the B3LYP exchange-correlation functional and MP2, with the MP2 values better in most cases. The results show that matching the experimental $\mathrm{pK}_{\mathrm{a}}$ can be used to predict the size of the first solvation shell in the +2 ions.
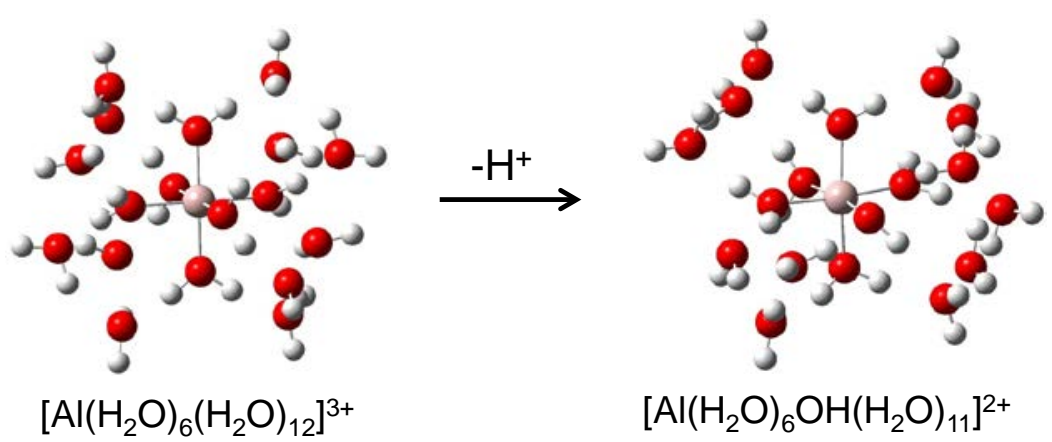

\section{Uranyl phosphates}

We have modeled the behavior of uranyl phosphate complexes in the environment and the structures have shown a great deal of diversity in the binding modes between the uranyl cation and phosphate anions. The energetics of anhydrous and hydrated complexes of $\mathrm{UO}_{2}{ }^{2+}$ with the phosphate anions $\mathrm{H}_{2} \mathrm{PO}_{4}^{-}$, $\mathrm{HPO}_{4}{ }^{2-}$, and $\mathrm{PO}_{4}{ }^{3-}$ for up to three

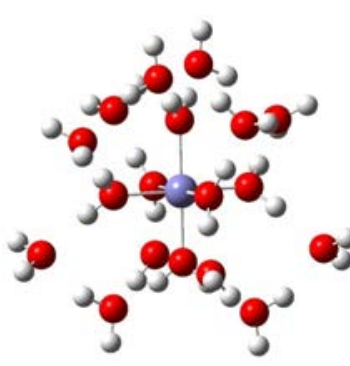

$\left[\mathrm{Fe}\left(\mathrm{H}_{2} \mathrm{O}\right)_{6}\left(\mathrm{H}_{2} \mathrm{O}\right)_{12}\right]^{3+}$

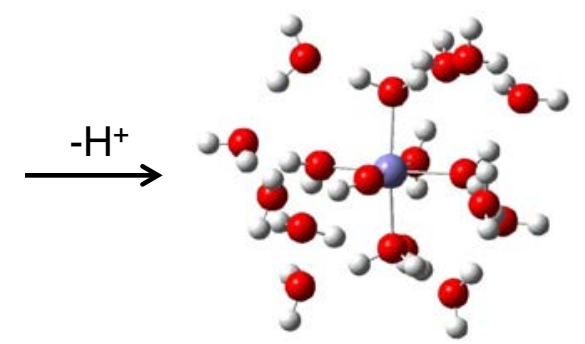

$\left[\mathrm{Fe}\left(\mathrm{H}_{2} \mathrm{O}\right)_{6} \mathrm{OH}\left(\mathrm{H}_{2} \mathrm{O}\right)_{11}\right]^{2+}$

Figure 1. Structures of $\mathrm{Al}^{3+}$ and $\mathrm{Fe}^{3+}$ complexes with two solvation shells. phosphorus ligands were studied at the density functional theory (DFT) and MP2 molecular orbital theory levels as isolated gas phase species and in aqueous solution by using selfconsistent reaction field (SCRF) calculations with different solvation models. The geometries, and vibrational frequencies of the major binding modes for these complexes are compared to experiment where possible and good agreement is found. Adequate steric space is available in these complexes to accommodate multiple water molecules in the equatorial region of the uranyl dication with up to two phosphorus ligands. The uranyl moiety is nonlinear in many of the complexes and coordination number $(\mathrm{CN}) 5$ in the equatorial plane is the predominant binding motif. The phosphates are found to bind in both monodentate and bidentate binding modes depending on the charge and the number of water molecules. The $\left[\mathrm{UO}_{2}\left(\mathrm{H}_{2} \mathrm{PO}_{4}\right)\left(\mathrm{H}_{2} \mathrm{O}\right)_{n}\right]^{+}$ complexes can accommodate up to three water molecules with the $\mathrm{H}_{2} \mathrm{PO}_{4}{ }^{-}$ligands remaining bidentate with a total equatorial $\mathrm{CN}$ of 5 . $\left[\mathrm{UO}_{2}\left(\mathrm{H}_{2} \mathrm{PO}_{4}\right)\left(\mathrm{H}_{2} \mathrm{O}\right)_{4}\right]^{+}$has an equatorial $\mathrm{CN}$ of 5 with the phosphate ligand bound in a monodentate fashion, and a strong hydrogen bond between the $\mathrm{H}$ atom on an equatorial water and the terminal $\mathrm{P}=\mathrm{O}$ group of $\mathrm{H}_{2} \mathrm{PO}_{4}{ }^{-}$. In the $\mathrm{UO}_{2}\left(\mathrm{HPO}_{4}\right)\left(\mathrm{H}_{2} \mathrm{O}\right)_{\mathrm{n}}$ complexes, protons can be abstracted from bound waters due to the increased negative charge on the $\mathrm{HPO}_{4}{ }^{2-}$ ligand forming $\mathrm{OH}^{-}$and $\mathrm{H}_{2} \mathrm{PO}_{4}{ }^{-}$ligands which equalizes the buildup of regions of negative charge. In $\mathrm{UO}_{2}\left(\mathrm{HPO}_{4}\right)\left(\mathrm{H}_{2} \mathrm{O}\right)_{3}$, the phosphate ligand is actually the $\mathrm{H}_{2} \mathrm{PO}_{4}{ }^{-}$moiety bound in a monodentate fashion and results from the abstraction of a proton from a water forming a hydroxide ligand bound to uranium leading to $\mathrm{CN} 4$. A hydrogen bond from the terminal $\mathrm{P}=\mathrm{O}$ group to the $\mathrm{H}$ atom of a water stabilizes the monodentate mode. This hydrogen bond results in an elongated $\mathrm{H}-\mathrm{OH}$ water bond and a 'hydroxide-like' interaction of this water with the uranyl center. In $\mathrm{UO}_{2}\left(\mathrm{HPO}_{4}\right)\left(\mathrm{H}_{2} \mathrm{O}\right)_{4}$, all of the ligands retain their identities. The $\mathrm{HPO}_{4}{ }^{2-}$ ligand is bound 
Table 1. Predicted pKa's of Metal Ions. Energies in kcal $/ \mathrm{mol}$.

\begin{tabular}{|c|c|c|c|c|c|c|c|c|}
\hline $\begin{array}{c}\text { Metal ion } / \mathrm{H}_{2} \mathrm{O} \\
\text { complex }\end{array}$ & $\begin{array}{c}\text { Charge } \\
\text { metal } \\
+n\end{array}$ & $\begin{array}{c}\text { Charge } \\
\text { metal } \\
+n-1\end{array}$ & $\begin{array}{c}\Delta \mathbf{G}_{\text {gas }} \\
\text { B3LYP }\end{array}$ & $\begin{array}{l}\Delta \mathbf{G}_{\text {gas }} \\
\text { MP2 }\end{array}$ & $\begin{array}{l}\text { Calc pKa } \\
\text { B3LYP }\end{array}$ & $\begin{array}{l}\text { Calc pK } \\
\text { MP2 }\end{array}$ & $\begin{array}{c}\mathrm{pK}_{\mathrm{a}} \\
\mathrm{MP2} \\
\text { error }\end{array}$ & $\begin{array}{l}\text { Exp } \\
\text { pK }_{\mathbf{a}}\end{array}$ \\
\hline $\begin{array}{l}{\left[\mathrm{Be}\left(\mathrm{H}_{2} \mathrm{O}\right)_{4}\right]^{2+}} \\
{\left[\mathrm{Be}\left(\mathrm{H}_{2} \mathrm{O}\right)_{3} \mathrm{OH}\right]^{+}}\end{array}$ & 0.12 & 0.17 & 116.3 & 111.2 & -1.7 & -5.4 & -0.3 & -5.7 \\
\hline $\begin{array}{l}{\left[\mathrm{Be}\left(\mathrm{H}_{2} \mathrm{O}\right)_{6}\right]^{2+}} \\
{\left[\mathrm{Be}\left(\mathrm{H}_{2} \mathrm{O}\right)_{5} \mathrm{OH}\right]^{+}}\end{array}$ & 0.34 & 0.14 & 116.0 & 108.9 & -11.3 & -16.5 & & -5.7 \\
\hline $\begin{array}{l}{\left[\mathrm{Mg}\left(\mathrm{H}_{2} \mathrm{O}\right)_{6}\right]^{2+}} \\
{\left[\mathrm{Mg}\left(\mathrm{H}_{2} \mathrm{O}\right)_{5} \mathrm{OH}\right]^{+}}\end{array}$ & 1.66 & 1.54 & 154.3 & 153.4 & 12.7 & 11.8 & -0.4 & $11.4^{\mathrm{a}}$ \\
\hline $\begin{array}{l}{\left[\mathrm{Ca}\left(\mathrm{H}_{2} \mathrm{O}\right)_{6}\right]^{2+}} \\
{\left[\mathrm{Ca}\left(\mathrm{H}_{2} \mathrm{O}\right)_{5} \mathrm{OH}\right]^{+}}\end{array}$ & 1.84 & 1.74 & 158.8 & 157.3 & 12.7 & 11.6 & 1.1 & $12.7^{\mathrm{a}}$ \\
\hline $\begin{array}{l}{\left[\mathrm{Ca}\left(\mathrm{H}_{2} \mathrm{O}\right)_{7}\right]^{2+}} \\
{\left[\mathrm{Ca}\left(\mathrm{H}_{2} \mathrm{O}\right)_{6} \mathrm{OH}\right]^{+}}\end{array}$ & 1.43 & 1.35 & 162.2 & 160.4 & 13.3 & 12.1 & 0.6 & $12.7^{\mathrm{a}}$ \\
\hline $\begin{array}{l}\left.\mathrm{Ca}\left(\mathrm{H}_{2} \mathrm{O}\right)_{8}\right]^{2+} \\
{\left[\mathrm{Ca}\left(\mathrm{H}_{2} \mathrm{O}\right)_{7} \mathrm{OH}\right]^{+}}\end{array}$ & 1.40 & 1.33 & 161.2 & 164.0 & 9.8 & 11.8 & 0.9 & $12.7^{\mathrm{a}}$ \\
\hline $\begin{array}{l}{\left[\mathrm{Sr}\left(\mathrm{H}_{2} \mathrm{O}\right)_{6}\right]^{2+}} \\
{\left[\mathrm{Sr}\left(\mathrm{H}_{2} \mathrm{O}\right)_{5} \mathrm{OH}\right]^{+}}\end{array}$ & 1.59 & 1.54 & 164.4 & 156.8 & 14.7 & 9.1 & & $13.2^{\mathrm{a}}$ \\
\hline $\begin{array}{l}{\left[\mathrm{Sr}\left(\mathrm{H}_{2} \mathrm{O}\right)_{7}\right]^{2+}} \\
{\left[\mathrm{Sr}\left(\mathrm{H}_{2} \mathrm{O}\right)_{6} \mathrm{OH}\right]^{+}}\end{array}$ & 1.55 & 1.50 & 169.2 & 162.1 & 17.4 & 12.2 & 1.0 & $13.2^{\mathrm{a}}$ \\
\hline $\begin{array}{l}{\left[\mathrm{Sr}\left(\mathrm{H}_{2} \mathrm{O}\right)_{8}\right]^{2+}} \\
{\left[\mathrm{Sr}\left(\mathrm{H}_{2} \mathrm{O}\right)_{7} \mathrm{OH}\right]^{+}}\end{array}$ & 1.88 & 1.47 & 172.2 & 175.1 & 16.3 & 18.4 & & $13.2^{\mathrm{a}}$ \\
\hline $\begin{array}{l}{\left[\mathrm{Mn}\left(\mathrm{H}_{2} \mathrm{O}\right)_{6}\right]^{2+}} \\
{\left[\mathrm{Mn}\left(\mathrm{H}_{2} \mathrm{O}\right)_{5} \mathrm{OH}\right]^{+}}\end{array}$ & 1.10 & 1.00 & 151.2 & 153.9 & 9.1 & 11.1 & -0.5 & $10.6^{\mathrm{C}}$ \\
\hline $\begin{array}{l}{\left[\mathrm{Fe}\left(\mathrm{H}_{2} \mathrm{O}\right)_{6}\right]^{2+}} \\
{\left[\mathrm{Fe}\left(\mathrm{H}_{2} \mathrm{O}\right)_{5} \mathrm{OH}\right]^{+}}\end{array}$ & 1.72 & 1.55 & 147.5 & 151.2 & 6.8 & 9.6 & -0.2 & $9.4^{\mathrm{a}}$ \\
\hline $\begin{array}{l}{\left[\mathrm{Co}\left(\mathrm{H}_{2} \mathrm{O}\right)_{6}\right]^{2+}} \\
{\left[\mathrm{Co}\left(\mathrm{H}_{2} \mathrm{O}\right)_{5} \mathrm{OH}\right]^{+}}\end{array}$ & 0.84 & 0.72 & 144.9 & 149.4 & 4.2 & 7.5 & 2.2 & $9.7^{\mathrm{c}}$ \\
\hline $\begin{array}{l}{\left[\mathrm{Ni}\left(\mathrm{H}_{2} \mathrm{O}\right)_{6}\right]^{2+}} \\
{\left[\mathrm{Ni}\left(\mathrm{H}_{2} \mathrm{O}\right)_{5} \mathrm{OH}\right]^{+}}\end{array}$ & 0.73 & 0.59 & 151.3 & 153.5 & 8.7 & 10.3 & -0.4 & $9.9^{\mathrm{c}}$ \\
\hline $\begin{array}{l}{\left[\mathrm{Cu}\left(\mathrm{H}_{2} \mathrm{O}\right)_{6}\right]^{2+}} \\
{\left[\mathrm{Cu}\left(\mathrm{H}_{2} \mathrm{O}\right)_{5} \mathrm{OH}\right]^{+}}\end{array}$ & 0.71 & 0.61 & 135.9 & 144.8 & 0.1 & 6.6 & 0.9 & $7.5^{\mathrm{c}}$ \\
\hline$\left[\mathrm{Zn}\left(\mathrm{H}_{2} \mathrm{O}\right)_{6}\right]^{2+}$ & 0.91 & 0.79 & 144.9 & 147.0 & 7.4 & 9.0 & 0.0 & $9.0^{\mathrm{C}}$ \\
\hline
\end{tabular}




\begin{tabular}{|c|c|c|c|c|c|c|c|c|}
\hline$\left[\mathrm{Zn}\left(\mathrm{H}_{2} \mathrm{O}\right)_{5} \mathrm{OH}\right]^{+}$ & & & & & & & & \\
\hline $\begin{array}{l}{\left[\mathrm{Cd}\left(\mathrm{H}_{2} \mathrm{O}\right)_{6}\right]^{2+}} \\
{\left[\mathrm{Cd}\left(\mathrm{H}_{2} \mathrm{O}\right)_{5} \mathrm{OH}\right]^{+}}\end{array}$ & 1.34 & 1.10 & 152.7 & 157.2 & 7.2 & 10.6 & -0.5 & $10.1^{\mathrm{c}}$ \\
\hline $\begin{array}{l}{\left[\mathrm{Pb}\left(\mathrm{H}_{2} \mathrm{O}\right)_{8}\right]^{2+}} \\
\left.\mathrm{Pb}\left(\mathrm{H}_{2} \mathrm{O}\right)_{7} \mathrm{OH}\right]^{+}\end{array}$ & 1.45 & 1.14 & 156.7 & 155.7 & 3.6 & 2.8 & & $7.6^{\mathrm{c}}$ \\
\hline $\begin{array}{l}{\left[\mathrm{Pb}\left(\mathrm{H}_{2} \mathrm{O}\right)_{9}\right]^{2+}} \\
\left.\mathrm{Pb}\left(\mathrm{H}_{2} \mathrm{O}\right)_{8} \mathrm{OH}\right]^{+}\end{array}$ & 1.45 & 1.20 & 160.1 & 159.5 & 5.4 & 5.0 & 2.6 & $7.6^{\mathrm{c}}$ \\
\hline $\begin{array}{l}{\left[\mathrm{Pb}\left(\mathrm{H}_{2} \mathrm{O}\right)_{10}\right]^{2+}} \\
\left.\mathrm{Pb}\left(\mathrm{H}_{2} \mathrm{O}\right)_{9} \mathrm{OH}\right]^{+}\end{array}$ & 1.43 & 1.20 & 167.4 & 166.0 & 4.5 & 3.4 & & $7.6^{\mathrm{c}}$ \\
\hline $\begin{array}{l}{\left[\mathrm{UO}_{2}\left(\mathrm{H}_{2} \mathrm{O}\right)_{3}\right]^{2+}} \\
{\left[\mathrm{UO}_{2}\left(\mathrm{H}_{2} \mathrm{O}\right)_{2} \mathrm{OH}\right]^{+}}\end{array}$ & 1.36 & 1.04 & 104.5 & 105.8 & -12.4 & -11.5 & & $-5.25^{b}$ \\
\hline $\begin{array}{l}{\left[\mathrm{UO}_{2}\left(\mathrm{H}_{2} \mathrm{O}\right)_{4}\right]^{2+}} \\
{\left[\mathrm{UO}_{2}\left(\mathrm{H}_{2} \mathrm{O}\right)_{3} \mathrm{OH}\right]^{+}}\end{array}$ & 1.28 & 0.97 & 120.1 & 120.5 & -9.8 & -9.6 & & $-5.25^{b}$ \\
\hline $\begin{array}{l}{\left[\mathrm{UO}_{2}\left(\mathrm{H}_{2} \mathrm{O}\right)_{5}\right]^{2+}} \\
{\left[\mathrm{UO}_{2}\left(\mathrm{H}_{2} \mathrm{O}\right)_{4} \mathrm{OH}\right]^{+}}\end{array}$ & 1.21 & 0.88 & 132.4 & 133.4 & -6.3 & -5.8 & -0.6 & $-5.25^{b}$ \\
\hline $\begin{array}{l}{\left[\mathrm{UO}_{2}\left(\mathrm{H}_{2} \mathrm{O}\right)_{6}\right]^{2+}} \\
{\left[\mathrm{UO}_{2}\left(\mathrm{H}_{2} \mathrm{O}\right)_{5} \mathrm{OH}\right]^{+}}\end{array}$ & 1.52 & 1.90 & 130.6 & 133.3 & -12.4 & -10.2 & & $-5.25^{b}$ \\
\hline $\begin{array}{l}{\left[\mathrm{Al}\left(\mathrm{H}_{2} \mathrm{O}\right)_{6}\right]^{3+}} \\
{\left[\mathrm{Al}\left(\mathrm{H}_{2} \mathrm{O}\right)_{5} \mathrm{OH}\right]^{2+}}\end{array}$ & 2.27 & 2.12 & 29.1 & 27.1 & -5.0 & -6.5 & & $5.0^{\mathrm{a}}$ \\
\hline $\begin{array}{l}{\left[\mathrm{Al}\left(\mathrm{H}_{2} \mathrm{O}\right)_{6}\left(\mathrm{H}_{2} \mathrm{O}\right)_{12}\right]^{3+}} \\
{\left[\mathrm{Al}\left(\mathrm{H}_{2} \mathrm{O}\right)_{6} \mathrm{OH}\left(\mathrm{H}_{2} \mathrm{O}\right)_{11}\right]^{2+}}\end{array}$ & 0.59 & 0.55 & 127.3 & 126.4 & 10.0 & 9.3 & -4.3 & $5.0^{\mathrm{a}}$ \\
\hline $\begin{array}{l}{\left[\mathrm{Fe}\left(\mathrm{H}_{2} \mathrm{O}\right)_{6}\right]^{3+}} \\
{\left[\mathrm{Fe}\left(\mathrm{H}_{2} \mathrm{O}\right)_{5} \mathrm{OH}\right]^{2+}}\end{array}$ & 2.41 & 2.03 & 10.6 & 19.7 & -16.4 & -9.8 & & $2.2^{\mathrm{a}}$ \\
\hline $\begin{array}{l}{\left[\mathrm{Fe}\left(\mathrm{H}_{2} \mathrm{O}\right)_{6}\left(\mathrm{H}_{2} \mathrm{O}\right)_{12}\right]^{3+}} \\
{\left[\mathrm{Fe}\left(\mathrm{H}_{2} \mathrm{O}\right)_{5} \mathrm{OH}\left(\mathrm{H}_{2} \mathrm{O}\right)_{12}\right]^{2+}}\end{array}$ & 0.65 & 0.76 & 114.2 & 120.0 & -0.2 & 4.1 & -1.9 & $2.2^{\mathrm{a}}$ \\
\hline
\end{tabular}

a Martell A.E. and R.M. Smith (2003). NIST Standard Reference Database 46 Version 7.0. NIST Critically Selected Stability Constants for Metal Complexes. ${ }^{b}$ Guillaumont, R., F. J. Mompean, et al. (2003). Update on the chemical thermodynamics of uranium, neptunium, plutonium, americium and technetium. Amsterdam; Boston; Paris, Elsevier ; Nuclear Energy Agency, Organisation for Economic Co-Operation and Development. ${ }^{\mathrm{c}}$ AR Felmy 
in a bidentate fashion to the uranyl and three water molecules are bound in the remaining sites resulting in $\mathrm{CN} 5$. The remaining water molecule is located in the second coordination sphere. Due to the steric effects of the second phosphate in the $\mathrm{UO}_{2}\left(\mathrm{H}_{2} \mathrm{PO}_{4}\right)_{2}\left(\mathrm{H}_{2} \mathrm{O}\right)_{n}$ and $\left[\mathrm{UO}_{2}\left(\mathrm{HPO}_{4}\right)_{2}\left(\mathrm{H}_{2} \mathrm{O}\right)_{n}\right]^{2-}$ hydrated complexes $(n=1-3)$, fewer water molecules can be accommodated equatorially as compared to the monoligand complexes. Bidentate coordination modes for the phosphate ligands are more common. The structure of $\mathrm{UO}_{2}\left(\mathrm{H}_{2} \mathrm{PO}_{4}\right)_{2}\left(\mathrm{H}_{2} \mathrm{O}\right)$ has bidentate $\mathrm{H}_{2} \mathrm{PO}_{4}{ }^{-}$ligands and a discrete bound water molecule resulting in the expected $\mathrm{CN} 5$. The $\mathrm{UO}_{2}\left(\mathrm{H}_{2} \mathrm{PO}_{4}\right)_{2}\left(\mathrm{H}_{2} \mathrm{O}\right)_{3}$ complex is structurally similar to the $\mathrm{UO}_{2}\left(\mathrm{H}_{2} \mathrm{PO}_{4}\right)_{2}\left(\mathrm{H}_{2} \mathrm{O}\right)_{2}$ complex, with the exception both $\mathrm{H}_{2} \mathrm{PO}_{4}^{-}$ligands are bound in a monodentate fashion. For the $\left[\mathrm{UO}_{2}\left(\mathrm{HPO}_{4}\right)_{2}\left(\mathrm{H}_{2} \mathrm{O}\right)_{n}\right]^{2-}(n=1$ and 3$)$ complexes, the equatorial $\mathrm{CN}$ was found to be four rather than five with both complexes having at least one phosphate with monodentate binding. The $\left[\mathrm{UO}_{2}\left(\mathrm{HPO}_{4}\right)_{2}\left(\mathrm{H}_{2} \mathrm{O}\right)_{2}\right]^{2-}$ complex however, contains two bidentate $\mathrm{HPO}_{4}{ }^{2-}$ with $\mathrm{CN} 6$ and $\mathrm{C}_{2 \mathrm{v}}$ symmetry. In $\left[\mathrm{UO}_{2}\left(\mathrm{HPO}_{4}\right)_{2}\left(\mathrm{H}_{2} \mathrm{O}\right)_{3}\right]^{2-}$, both phosphate ligands exist as $\mathrm{H}_{2} \mathrm{PO}_{4}{ }^{-}$moieties with two hydroxide ligands bound to the uranyl. The hydroxides are hydrogen bonded to $\mathrm{H}$ atoms from the phosphate ligands and the remaining water acts as a second sphere water molecule hydrogen bonded to the hydroxide ligands. The $\left[\mathrm{UO}_{2}\left(\mathrm{PO}_{4}\right)\left(\mathrm{H}_{2} \mathrm{O}\right)_{n}\right]^{-}(n=1,2$ and 4) complexes each have $\mathrm{CN} 4$ and some bidentate phosphate binding as do the $\left[\mathrm{UO}_{2}\left(\mathrm{PO}_{4}\right)_{2}\left(\mathrm{H}_{2} \mathrm{O}\right)_{n}\right]^{4-}(n=1-2)$ complexes. The $(\mathrm{n}=3)$ complexes has $\mathrm{CN} 5$ with the $\mathrm{PO}_{4}{ }^{3-}$ ligand forming a bidentate bond to the uranyl dication. In $\left[\mathrm{UO}_{2}\left(\mathrm{PO}_{4}\right)_{2}\left(\mathrm{H}_{2} \mathrm{O}\right)\right]^{4-}$ both phosphate ligands are bidentate bound to the uranyl dication. In $\left[\mathrm{UO}_{2}\left(\mathrm{PO}_{4}\right)_{2}\left(\mathrm{H}_{2} \mathrm{O}\right)_{2}\right]^{4-}$, there is a proton transfer to a $\mathrm{PO}_{4}{ }^{3-}$ ligand leading to the formation of an $\mathrm{OH}^{-}$bonded to the $\mathrm{UO}_{2}{ }^{2+}$, a monodentate $\mathrm{HPO}_{4}{ }^{2-}$ ligand and one bidentate $\mathrm{PO}_{4}{ }^{3-}$ ligand.

A detailed benchmark study of the three $\mathrm{pK}_{\mathrm{a}}$ 's for phosphoric acid was performed to better understand the reactions of $\mathrm{UO}_{2}{ }^{2+}$ with phosphates. Table 2 shows the $\mathrm{pK}_{\mathrm{a}}$ 's of the first, second, and third deprotonations of phosphoric acid using the gas phase geometries optimized at the B3LYP/DZVP2 level, with single point energies at the MP2/aug-cc-pVnZ ( $=\mathrm{D}, \mathrm{T}$, and Q) levels plus single point self-consistent reaction field (SCRF) CPCM with COSMO-RS radii SCRF calculations as implemented in Gaussian 09. For the first deprotonation of $\mathrm{H}_{3} \mathrm{PO}_{4}$, all methods are within $2.4 \mathrm{pK}_{\mathrm{a}}$ unit of experiment with the exception of the MP2/aug-cc-pVDZ method which is within $4 \mathrm{pK}_{\mathrm{a}}$ units of experiment. For the second and third deprotonations of $\mathrm{H}_{3} \mathrm{PO}_{4}$, the B3LYP/DZVP2 method predicts the $\mathrm{pK}_{\mathrm{a}}$ 's to increase linearly as found by experiment but the slope is too large and the $\mathrm{pK}_{\mathrm{a}}$ 's are in error by $\sim 5$ and $10 \mathrm{pK}_{\mathrm{a}}$ units, respectively, as compared to experiment. The second $\mathrm{pK}_{\mathrm{a}}$ is within $\sim 2 \mathrm{pK}_{\mathrm{a}}$ of experiment. The MP2/aug-cc-pVnZ ( $\mathrm{n}=\mathrm{D}, \mathrm{T}$, and $\mathrm{Q})$ methods do not show a linear dependence for the $\mathrm{pK}_{\mathrm{a}}$ 's with the third $\mathrm{pK}_{\mathrm{a}}$ within $\sim 6 \mathrm{pK}_{\mathrm{a}}$ units.

The errors in the phosphate acidities can be reduced by using explicit waters of solvation. We used a microsolvation approach as shown in Table 3 which gives the solution free energies involving reactions of phosphorus-based ligands combined with water molecules to create microsolvated solutes in our continuum solution model. Table 3 shows the dependence of the energies of reactions (1) - (3) on different solvation methods.

$$
\begin{aligned}
& \mathrm{H}_{3} \mathrm{PO}_{4}\left(\mathrm{H}_{2} \mathrm{O}\right)_{4} \rightarrow \mathrm{H}_{2} \mathrm{PO}_{4}\left(\mathrm{H}_{2} \mathrm{O}\right)_{4}{ }^{-}+\mathrm{H}^{+} \\
& \mathrm{H}_{2} \mathrm{PO}_{4}\left(\mathrm{H}_{2} \mathrm{O}\right)_{4}{ }^{-} \rightarrow \mathrm{HPO}_{4}\left(\mathrm{H}_{2} \mathrm{O}\right)_{4}{ }^{2-}+\mathrm{H}^{+} \\
& \mathrm{HPO}_{4}\left(\mathrm{H}_{2} \mathrm{O}\right)_{4}{ }^{2-} \rightarrow \mathrm{PO}_{4}\left(\mathrm{H}_{2} \mathrm{O}\right)_{4}{ }^{-{ }^{-}}+\mathrm{H}^{+}
\end{aligned}
$$


Table 2. Phosphoric Acid $\mathrm{pK} \mathrm{K}_{\mathrm{a}}$ for the $1^{\text {st }}, 2^{\text {nd }}$, and $3^{\text {rd }}$ Deprotonation. ${ }^{\mathrm{a}}$

\begin{tabular}{lccc}
\hline Method & $\mathbf{1}^{\text {st }}$ & $\mathbf{2}^{\text {nd }}$ & $\mathbf{3}^{\mathbf{d}}$ \\
\hline B3LYP/DZVP2 & 0.2 & 12.4 & 22.0 \\
MP2/Aug-cc-pVDZ & -2.0 & 6.9 & 6.2 \\
MP2/Aug-cc-pVTZ & -0.2 & 8.8 & 8.2 \\
MP2/Aug-cc-pVQZ & -0.2 & 9.0 & 8.2 \\
CBS & -0.2 & 9.1 & 8.2 \\
Experiment $^{\mathrm{b}}$ & 2.15 & 7.20 & 12.35
\end{tabular}

${ }^{a}$ Geometries optimized at the B3LYP/DZVP2 level. Single point energies at the MP2 level with the augcc-pVnZ ( $\mathrm{n}=\mathrm{D}, \mathrm{T}$, and Q) basis sets and extrapolated to the complete basis set limit (CBS). $\mathrm{pK}_{\mathrm{a}}^{\text {'s }}$ calculated from the gas phase values at each level plus single point B3LYP/DZVP2 CPCM with COSMO-RS radii SCRF calculations. ${ }^{\mathrm{b}}$ CRC Handbook of Chemistry and Physics, 86th ed. Lide, D.R., Ed.; CRC Press: Boca Raton, FL, 2005-2006; Chapter 7, p 14

All of the solvation models predict the solution acidity $(\Delta \mathrm{G})$ for reaction (1) within $\sim 3 \mathrm{kcal} / \mathrm{mol}$ or $\sim 2 \mathrm{pK}_{\mathrm{a}}$ units. A similar result is found for reaction (2) with all of the models, except for the IEF-PCM with the UA0 and UFF radii models, giving reasonable results for the second $\mathrm{pK}_{\mathrm{a}}$ for $\mathrm{H}_{3} \mathrm{PO}_{4}$. The two exceptions predict free energies that are too positive. For the third $\mathrm{pK}_{\mathrm{a}}, \mathrm{CPCM}$ with COSMO-RS radii and IEF-PCM and CSC-PCM, both with the Pauling radii give reasonable agreement with experiment. Our calculated free energies value for all three reactions are closer to experiment than the previously calculated values (Tang, E.; Tommaso, D. D.; de Leeuw, N. H. Phys. Chem. Chem. Phys. 2010, 12, 13804-13815.) due in part to their use of an incorrect value for the free energy of hydration of $\mathrm{H}^{+}$. We used a value of $\Delta \mathrm{G}_{\text {solvation }}\left(\mathrm{H}^{+}\right)=-265.9$ $\mathrm{kcal} / \mathrm{mol}$ which is derived from experimental gas phase clustering energies and is consistent with our high level calculations using a microsolvation/SCRF approach with appropriate thermodynamic corrections. Tang et al. reported a $\mathrm{pK}_{\mathrm{a}}$ of 8.4 for reaction (3) which is $\sim 4 \mathrm{pK}_{\mathrm{a}}$ from experiment, but we were only able to closely match this result using a $\mathrm{PO}_{4}\left(\mathrm{H}_{2} \mathrm{O}\right)_{4}$ cluster in $\mathrm{C}_{1}$ symmetry that was $\sim 4 \mathrm{kcal} / \mathrm{mol}$ higher in energy than our lower energy $\mathrm{D}_{2 \mathrm{~d}}$ geometry, suggesting that Tang et al. did not use the lowest energy structure. In summary, our best predictions of the $\mathrm{pK}_{\mathrm{a}}$ 's for the different protonation states of phosphoric acid were obtained with a microsolvation approach with 4 waters as shown in reactions (1) - (3), MP2/aug-ccpVTZ for the gas phase values, and IEF-PCM with Pauling radii for the SCRF calculations. The first, second, and third acidities are now within -1.9, -0.8 , and $-1.2 \mathrm{pK}_{\mathrm{a}}$ units of experiment, respectively.

Table 3. MP2/aug-cc-pVTZ Reaction Free Energies in Solution of Solvated Phosphates/ $\mathrm{H}_{2} \mathrm{O}$ Complexes in $\mathrm{kcal} / \mathrm{mol}$.

\begin{tabular}{|c|c|c|c|c|c|c|c|c|c|c|}
\hline Rxn & $\begin{array}{l}\Delta \mathbf{H}_{298} \\
\text { gas }\end{array}$ & $\begin{array}{l}\Delta \mathbf{G}_{298} \\
\text { gas }\end{array}$ & $\begin{array}{l}\text { CPCM- } \\
\text { COSMO- } \\
\text { RS Radii }\end{array}$ & $\begin{array}{l}\text { IEF- } \\
\text { PCM } \\
\text { UA0 }\end{array}$ & $\begin{array}{l}\text { IEF- } \\
\text { PCM } \\
\text { UFF }\end{array}$ & IPCM & $\begin{array}{l}\text { IEF- } \\
\text { PCM } \\
\text { Pauling }^{\text {a }}\end{array}$ & $\begin{array}{l}\text { CSC- } \\
\text { PCM } \\
\text { Pauling }\end{array}$ & $\begin{array}{l}\text { Tang } \\
\text { et al. }\end{array}$ & Expt \\
\hline 1 & 312.6 & 307. & $\begin{array}{l}-0.0 \\
\end{array}$ & 5.5 & 0.7 & 2.9 & 0.4 & -0.4 & 8.6 & 7 \\
\hline 2 & 407.6 & 398.7 & 8.9 & 19.8 & 14.2 & 13.8 & 8.8 & 9.2 & 12.7 & 9.8 \\
\hline 3 & 512.2 & 507.6 & 13.4 & 23.7 & 26.5 & 29.9 & 15.2 & 16.7 & 11.7 & 16.9 \\
\hline
\end{tabular}

${ }^{\mathrm{a}}$ IEF-PCM using Pauling Radii. ${ }^{\mathrm{b}}$ CSC-PCM with Pauling Radii.

The SCRF calculations with the CPCM, IEF-PCM and IPCM models/parameterizations have been used to predict the behavior of these complexes in solution to investigate the 
thermodynamics of binding, and the equilibrium constants for the reactions of $\mathrm{UO}_{2}{ }^{2+}$ with phosphate and water ligands. These approaches were first tested on known reactions ((4)-(9)).

$$
\begin{aligned}
& {\left[\mathrm{UO}_{2}\left(\mathrm{H}_{2} \mathrm{O}\right)_{5}\right]^{2+}+\mathrm{H}_{3} \mathrm{PO}_{4}\left(\mathrm{H}_{2} \mathrm{O}\right)_{4} \rightarrow\left[\mathrm{UO}_{2}\left(\mathrm{H}_{2} \mathrm{PO}_{4}\right)\left(\mathrm{H}_{2} \mathrm{O}\right)_{4}\right]^{+}+\left[\mathrm{H}_{3} \mathrm{O}\left(\mathrm{H}_{2} \mathrm{O}\right)_{3}\right]^{+}+\mathrm{H}_{2} \mathrm{O}} \\
& {\left[\mathrm{UO}_{2}\left(\mathrm{H}_{2} \mathrm{O}\right)_{5}\right]^{2+}+\left[\mathrm{H}_{3} \mathrm{PO}_{4}\left(\mathrm{H}_{2} \mathrm{O}\right)_{4}\right] \rightarrow\left[\mathrm{UO}_{2}\left(\mathrm{H}_{3} \mathrm{PO}_{4}\right)\left(\mathrm{H}_{2} \mathrm{O}\right)_{4}\right]^{2+}+\mathrm{H}_{2} \mathrm{O}+\left(\mathrm{H}_{2} \mathrm{O}\right)_{4}} \\
& {\left[\mathrm{UO}_{2}\left(\mathrm{H}_{2} \mathrm{O}\right)_{5}\right]^{2+}+\left[\mathrm{H}_{2} \mathrm{PO}_{4}\left(\mathrm{H}_{2} \mathrm{O}\right)_{4}\right]^{-} \rightarrow\left[\mathrm{UO}_{2}\left(\mathrm{H}_{2} \mathrm{PO}_{4}\right)\left(\mathrm{H}_{2} \mathrm{O}\right)_{3}\right]^{+}+2\left(\mathrm{H}_{2} \mathrm{O}\right)+\left(\mathrm{H}_{2} \mathrm{O}\right)_{4}} \\
& {\left[\mathrm{H}_{2} \mathrm{PO}_{4}\left(\mathrm{H}_{2} \mathrm{O}\right)_{4}\right]^{-}+\mathrm{UO}_{2}\left(\mathrm{H}_{2} \mathrm{PO}_{4}\right)\left(\mathrm{H}_{2} \mathrm{O}\right)_{4}^{+} \rightarrow \mathrm{UO}_{2}\left(\mathrm{H}_{2} \mathrm{PO}_{4}\right)_{2}\left(\mathrm{H}_{2} \mathrm{O}\right)_{3}+\left(\mathrm{H}_{2} \mathrm{O}\right)+\left(\mathrm{H}_{2} \mathrm{O}\right)_{4}} \\
& {\left[\mathrm{UO}_{2}\left(\mathrm{H}_{2} \mathrm{O}\right)_{5}\right]^{2+}+\left[\mathrm{HPO}_{4}\left(\mathrm{H}_{2} \mathrm{O}\right)_{4}\right]^{2-} \rightarrow\left[\mathrm{UO}_{2}\left(\mathrm{HPO}_{4}\right)\left(\mathrm{H}_{2} \mathrm{O}\right)_{4}\right]+\left(\mathrm{H}_{2} \mathrm{O}\right)+\left(\mathrm{H}_{2} \mathrm{O}\right)_{4}} \\
& {\left[\mathrm{UO}_{2}\left(\mathrm{H}_{2} \mathrm{O}\right)_{5}\right]^{2+}+\left[\mathrm{PO}_{4}\left(\mathrm{H}_{2} \mathrm{O}\right)_{4}\right]^{3-} \rightarrow\left[\mathrm{UO}_{2}\left(\mathrm{PO}_{4}\right)\left(\mathrm{H}_{2} \mathrm{O}\right)_{3}\right]^{-}+2\left(\mathrm{H}_{2} \mathrm{O}\right)+\left(\mathrm{H}_{2} \mathrm{O}\right)_{4}}
\end{aligned}
$$

The cavity effects were studied using the same approaches and radii as used for the phosphoric acidities. The data in Table 4 shows that the IPCM solvation model consistently agrees best with experiment in reactions in which the hydrated uranyl dication is involved. The best agreement between the calculated and experimental values for reactions $(4)-(9)$ is found when the waters displaced from hydrated $\mathrm{UO}_{2}{ }^{2+}$ become free waters in the products. There is less of an effect if the waters about the $\mathrm{H}_{\mathrm{x}} \mathrm{PO}_{4}{ }^{\mathrm{y}-}$ are treated as a cluster or as free waters.

Use of our carefully benchmarked hybrid microsolvation-continuum approach led to the prediction that $\left[\mathrm{H}_{2} \mathrm{PO}_{4}\right]^{-}$will displace two $\mathrm{H}_{2} \mathrm{O}$ molecule from $\left[\mathrm{UO}_{2}\left(\mathrm{H}_{2} \mathrm{PO}_{4}\right)\left(\mathrm{H}_{2} \mathrm{O}\right)_{3}\right]^{+}$to exothermically form neutral $\left[\mathrm{UO}_{2}\left(\mathrm{H}_{2} \mathrm{PO}_{4}\right)_{2}\left(\mathrm{H}_{2} \mathrm{O}\right)\right]$. An additional $\left[\mathrm{H}_{2} \mathrm{PO}_{4}\right]^{-}$will displace the remaining water to form the $\left[\mathrm{UO}_{2}\left(\mathrm{H}_{2} \mathrm{PO}_{4}\right)_{3}\right]^{-}$anion exothermically in solution. The addition of $\left[\mathrm{H}_{2} \mathrm{PO}_{4}\right]^{-}$to $\left[\mathrm{UO}_{2}\left(\mathrm{H}_{2} \mathrm{PO}_{4}\right)_{2}\left(\mathrm{H}_{2} \mathrm{O}\right)_{3}\right]$ with all three waters displaced is even more exothermic. $\mathrm{HPO}_{4}{ }^{2-}$ will displace two waters from $\left[\mathrm{UO}_{2}\left(\mathrm{HPO}_{4}\right)\left(\mathrm{H}_{2} \mathrm{O}\right)_{4}\right]$ to form $\left[\mathrm{UO}_{2}\left(\mathrm{HPO}_{4}\right)_{2}\left(\mathrm{H}_{2} \mathrm{O}\right)_{2}\right]^{2-}$ exothermically. $\left[\mathrm{UO}_{2}\left(\mathrm{HPO}_{4}\right)\left(\mathrm{H}_{2} \mathrm{O}\right)_{3}\right]$ is predicted to be a strong base in the gas phase and in aqueous solution and a moderate to weak acid in the gas phase and a weak acid in solution. Our results show that one has to be careful in the type of solvent model that is used and also in the type of reaction to be used in the model. Overall, the results show that it is possible to predict the energetic properties of aquo uranyl phosphate complexes using correlated molecular orbital theory in combination with SCRF approaches. The prediction of the solution energetics still

\begin{tabular}{|c|c|c|c|c|c|c|c|c|c|}
\hline $\mathbf{R x n}$ & $\Delta \mathbf{H}_{298}$ & $\Delta \mathbf{G}_{298}$ & $\begin{array}{l}\text { CPCM- } \\
\text { COSMO- } \\
\text { RS Radii }\end{array}$ & $\begin{array}{l}\text { IEF- } \\
\text { PCM } \\
\text { UA0 }\end{array}$ & $\begin{array}{l}\text { IEF- } \\
\text { PCM } \\
\text { UFF }\end{array}$ & IPCM & $\begin{array}{l}\text { IEF- } \\
\text { PCM- } \\
\text { Pauling }^{\text {a }}\end{array}$ & $\begin{array}{l}\text { CSC- } \\
\text { PCM } \\
\text { Pauling }^{b}\end{array}$ & $\begin{array}{l}\operatorname{Exp} \\
\Delta G_{\text {sol }}\end{array}$ \\
\hline 5 & -77.8 & -87.6 & -2.2 & -11.3 & 0.9 & -0.6 & -3.4 & 0.7 & -1.0 \\
\hline $6 b$ & -10.3 & -19.7 & -3.4 & -13.0 & -1.4 & 0.9 & -6.6 & -1.5 & -1.0 \\
\hline $7 b$ & -164.0 & -185.1 & -22.4 & -30.2 & -22.5 & -8.0 & -23.8 & -18.1 & -3.99 \\
\hline $8 b$ & -91.0 & -101.2 & -19.7 & -22.8 & -21.4 & -5.1 & -19.0 & -16.7 & -6.70 \\
\hline $9 b$ & -334.7 & -341.5 & -25.2 & -41.3 & -33.5 & -2.6 & -21.0 & -17.1 & -8.2 \\
\hline $10 \mathrm{~b}$ & -489.7 & -510.0 & -26.2 & -39.8 & -37.3 & -13.9 & -19.4 & -17.7 & -15.4 \\
\hline
\end{tabular}
requires the continued development of solvent modeling approaches as small changes in the models can lead to large changes in reaction energies in solution. This work has been submitted for publication to J. Phys. Chem. A.

Table 4. MP2 Calculated Reaction Energies of $\mathrm{UO}_{2}{ }^{2+} /$ Solvated Phosphates/ $\mathrm{H}_{2} \mathrm{O}$ Complexes in $\mathrm{kcal} / \mathrm{mol}$.

${ }^{\mathrm{a}}$ IEF-PCM using Pauling Radii. ${ }^{\mathrm{b}}$ CSC-PCM with Pauling Radii. 


\section{Atmospheric chemistry}

There is substantial interest in the role of halogen oxides in the stratosphere, especially for ozone depletion. One of the key reactions involving halogen oxides that lead to the catalytic destruction of stratospheric ozone is the self-reaction of halogen oxides (Reaction (1)),

$$
\mathrm{XO}+\mathrm{XO}+\mathrm{M} \rightarrow 2 \mathrm{X}+\mathrm{O}_{2}+\mathrm{M}
$$

The halogen atom $(\mathrm{X})$ resulting from this reaction can participate in known catalytic reactions to destroy ozone via Reaction sequence (2)

$$
\begin{aligned}
& \mathrm{X}+\mathrm{O}_{3} \rightarrow \mathrm{XO}+\mathrm{O}_{2} \\
& \mathrm{XO}+\mathrm{O} \rightarrow \mathrm{X}+\mathrm{O}_{2} \\
& \text { Net: } \mathrm{O}+\mathrm{O}_{3} \rightarrow 2 \mathrm{O}_{2}
\end{aligned}
$$

The above catalytic cycle, originally proposed by Rowland and Molina, is used to describe ozone destruction by halogens in the stratosphere. In regions where oxygen atom abundances are low, but halogen oxide concentrations are high, a halogen oxide dimer or "XO dimer" mechanism for the destruction of ozone plays an important role in catalytically destroying ozone via reaction sequence (12), which yields the net reaction (11c).

$$
\begin{aligned}
& \mathrm{XO}+\mathrm{XO}+\mathrm{M} \rightarrow \mathrm{XOOX}+\mathrm{M} \\
& \mathrm{XOOX}+h v \rightarrow \mathrm{XOO}+\mathrm{X} \\
& \mathrm{XOO}+\mathrm{M} \rightarrow \mathrm{X}+\mathrm{O}_{2}+\mathrm{M} \\
& 2\left[\mathrm{X}+\mathrm{O}_{3} \rightarrow \mathrm{XO}+\mathrm{O}_{2}\right]
\end{aligned}
$$

There are several major assumptions with the above chemistry. One assumption is that when two $\mathrm{XO}$ radicals combine in a three body collision, a XOOX dimer is formed. The second assumption is that the resulting XOO radical that is formed from the photodissociation of the $\mathrm{XOOX}$ dimer is only marginally stable to render its facile decomposition into $\mathrm{X}$ atoms and $\mathrm{O}_{2}$.

In addition to the well-known role of the chlorine oxides in the atmospheric process of ozone depletion, the analogous bromine oxides also play an important role. Bromine's potential for ozone depletion is $\sim 40$ times larger as compared to that of chlorine. An estimated $40 \%$ of the ozone depletion in the Antarctic and Arctic stratosphere may be due to bromine oxides. There is considerable interest in the role of iodine chemistry in the atmosphere due to formation of its compounds in the marine boundary layer (MBL), and its potential for the destruction of $\mathrm{O}_{3}$ by cycles involving $\mathrm{IO}, \mathrm{HOI}, \mathrm{OIO}$, and $\mathrm{INO}_{3}$. It is known that iodine at the MBL can lead to the activation of chlorine and bromine from sea-salt aerosol due to the presence of iodocarbons in the open ocean. The self-reactions of halogen oxides are interesting reactions not only from the stand-point of their significant role in ozone depletion reactions, but also from the fundamental perspective that these reactions may proceed through long-lived collision complexes on complex potential energy surfaces. The rates of halogen oxide self-reactions will be governed by the rates at which complexes are formed and by the stabilities and rates of their decomposition. These subtleties are manifested experimentally in the rate coefficients that exhibit significant pressure dependences, negative temperature dependences, and product distributions, which also depend on the pressure.

High level $a b$ initio electronic structure calculations at the coupled cluster level with a correction for triples extrapolated to the complete basis set limit have been made for the thermodynamics of the $\mathrm{BrBrO}_{2}, \mathrm{IIO}_{2}, \mathrm{ClBrO}_{2}, \mathrm{ClIO}_{2}$, and $\mathrm{BrIO}_{2}$ isomers, as well as various molecules involved in the bond dissociation processes. The results showed a broad range of chemistries with no real 
periodic behavior. The inclusion of spin orbit effects was critical to getting the correct qualitative picture of the potential energy surfaces when I is present. Of the $\mathrm{BrBrO}_{2}$ isomers, $\mathrm{BrOOBr}$ is predicted to be the most stable by 8.5 and $9.3 \mathrm{kcal} / \mathrm{mol}$ compared to $\mathrm{BrBrO}_{2}$ and $\mathrm{BrOBrO}$ at 298 $\mathrm{K}$, respectively. The weakest bond in $\mathrm{BrOOBr}$ is the $\mathrm{O}-\mathrm{Br}$ bond with a bond dissociation energy (BDE) of $15.3 \mathrm{kcal} / \mathrm{mol}$, and in $\mathrm{BrBrO}_{2}$, it is the $\mathrm{Br}-\mathrm{Br}$ bond of $19.1 \mathrm{kcal} / \mathrm{mol}$. The smallest BDE in $\mathrm{BrOBrO}$ is for the central $\mathrm{O}-\mathrm{Br}$ bond with a $\mathrm{BDE}$ of $12.6 \mathrm{kcal} / \mathrm{mol}$. Of the $\mathrm{IIO}_{2}$ isomers, $\mathrm{IIO}_{2}$ is predicted to be the most stable by $3.3,9.4$, and $28.9 \mathrm{kcal} / \mathrm{mol}$ compared to IOIO, IOOI, and OIIO at $298 \mathrm{~K}$, respectively. The weakest bond in $\mathrm{IIO}_{2}$ is the I-I bond with a $\mathrm{BDE}$ of 22.2 $\mathrm{kcal} / \mathrm{mol}$. The smallest BDEs in IOIO and IOOI are the terminal O-I bonds with values of 19.0 and $5.2 \mathrm{kcal} / \mathrm{mol}$, respectively. The calculated surfaces help to explain crossed molecular beam scattering results for the reactions of $\mathrm{O}$ atoms with $\mathrm{X}_{2}$ and $\mathrm{XY}$ in terms of the well depths on the triplet potential energy surfaces. In the case of the $\mathrm{ClO}+\mathrm{ClO}$ self reaction, all three isomers have been experimentally isolated. In the case of $\mathrm{BrO}$ and $\mathrm{IO}$, little is known experimentally about the complexes. The $\mathrm{BrO}$ self-reaction is very similar to its chlorine analogue, in that the two important stable complexes are $\mathrm{BrOOBr}$ and $\mathrm{BrOBrO}$ that the reaction proceeds through. The $\mathrm{BrOOBr}$ is less stable than $\mathrm{ClOOCl}$ and the favorable decomposition channel is the formation of $\mathrm{Br}+\mathrm{BrOO}$. The iodine oxide (IO) self reaction favors the formation of the IOIO complex, which is the least stable complex for the $\mathrm{ClO}$ and $\mathrm{BrO}$ self reactions. However, given that the IO self-reaction also favors the formation of IOOI, the branching ratios for the formation of the complexes are going to be important in establishing the partitioning between iodinecontaining species in the reaction. Unlike the $\mathrm{ClO}$ and $\mathrm{BrO}$ self-reaction decomposition channels, in which the major stable products are halogen atoms ( $\mathrm{Cl}$ or $\mathrm{Br}$ atoms) and molecular oxygen, the IO self reaction potential energy surface suggests that OIO, iodine atoms, and molecular oxygen are going to be major stable products. This is consistent with experimental studies on the IO self-reaction which showed the formation of gas phase OIO.

Not surprisingly, little is known about the cross halogen oxide reactions, i.e. $\mathrm{ClO}+\mathrm{BrO}, \mathrm{ClO}+$ $\mathrm{IO}$, and $\mathrm{BrO}+\mathrm{IO}$. Experimentally, these reactions are quite complex to study and the determination of the channels leading to any observe stable products let alone their branching ratios because of the multiplicity of channels is difficult. There are some interesting observations for future experimental studies in regards to the speciation from the cross halogen oxide reactions. For example, in the $\mathrm{ClO}+\mathrm{BrO}$ cross reaction, $\mathrm{OClO}$ is expected to be a major product, but $\mathrm{OBrO}$ is expected to be negligible. In the $\mathrm{ClO}+\mathrm{IO}$ cross reaction, $\mathrm{OClO}$ could be formed but little OIO is expected, whereas in the case of the $\mathrm{BrO}+\mathrm{IO}$ cross reaction, the OIO species is expected to be a major product. In an experimental study of the $\mathrm{BrO}+\mathrm{IO}$ reaction, only $\mathrm{OIO}$ is observed and no evidence of $\mathrm{OBrO}$ is found. In discharge flow mass spectroscopic experimental studies of $\mathrm{ClO}+\mathrm{IO}$, only $\mathrm{OClO}$ is observed and not OIO, consistent with the predictions from the potential energy surface. $\mathrm{Cl}$ atoms and $\mathrm{ICl}$ were also observed in these experiments, and these products can be explained by the channels giving $\mathrm{Cl}+\mathrm{IOO}$ and $\mathrm{I}+$ $\mathrm{ClOO}$. Both the IOO and $\mathrm{ClOO}$ are weakly bound and will produce $\mathrm{Cl}$ and I atoms, respectively. The recombination of $\mathrm{Cl}$ and I atoms to give $\mathrm{ICl}$ is consistent with the experimental results. This work was published in "Thermodynamic Properties of the $\mathrm{XO}_{2}, \mathrm{X}_{2} \mathrm{O}, \mathrm{XYO}, \mathrm{X}_{2} \mathrm{O}_{2}$, and $\mathrm{XYO}_{2}$ $(\mathrm{X}, \mathrm{Y}=\mathrm{Cl}, \mathrm{Br}$ and I) Isomers," by D. J. Grant, E. B. Garner III, M. H. Matus, M. T. Nguyen, K. A. Peterson, J. S. Francisco, and D. A. Dixon, J. Phys. Chem. A, 2010, 114, 4254-4265.

\section{Alkali Metal and Alkaline Earth Compounds}


Alkali metals are present in the upper atmosphere and the source of alkali metals in the mesosphere is considered to be mostly meteoritic with layers containing atomic alkali metals observed at about $90 \mathrm{~km}$. Atomic alkali metals (especially $\mathrm{Na}$ ) are oxidized in the upper atmosphere forming the neutral oxides and hydroxides. Superoxides, formed by recombination reactions with $\mathrm{O}_{2}$, are considered to be the main sink of the metal atoms beneath these layers. There is substantial interest in the role of alkali metal compounds that can be formed in the combustion of coal and other fuel sources, for example added biofuels. Alkali compounds can be formed from precursors in the fuel and from additives; examples include calcite or dolomite, which are used to remove sulfur. The alkali compounds formed during combustion have been implicated in fouling, corrosion, erosion, and agglomeration processes in power plants. The alkali compounds can form fine particulates which are readily trapped on tube surfaces and can inhibit the stable operation of a coal-fired power plant leading to undesirable slagging, fouling, and corrosion in the boilers. In addition, alkali-based particulates can lead to the corrosion of gas turbine blades in commercial pressurized fluidized bed combustion reactors. Ash particles containing alkalis can be deposited on various combustor components causing serious damage, especially for gas turbine blades directly exposed to the combustion region. The roles of alkali metal compounds in atmospheric and combustion chemistry are important reasons as to why high quality information about bond energies and heats of formation of alkali compounds are of interest.

Compounds containing the alkaline earth metals are commonly occurring substances in nature (calcium and magnesium are the fifth and eighth most abundant elements in the Earth's crust) and are used on a daily basis as part of the chemical industry. We are particularly interested in the thermochemical properties of the chlorides, fluorides, oxides and hydroxides of $\mathrm{Be}, \mathrm{Mg}$ and Ca. Magnesium oxide is used for lining furnaces, and calcium hydroxide (slaked lime) is the principal ingredient in plaster and mortar. Calcium chloride absorbs water from the air and it is used in the prevention of dust on roads, coal, and tennis courts and also as a drying agent in the laboratory. The alkaline earth monoxides play an important role in flame chemistry, in fuels (MgO) and possibly in stellar atmospheres.

Geometry parameters, frequencies, heats of formation and bond dissociation energies were predicted for simple alkali metal compounds (hydrides, chlorides, fluorides, hydroxides and oxides) of $\mathrm{Li}, \mathrm{Na}$ and $\mathrm{K}$ from coupled cluster theory [CCSD(T)] calculations including corevalence correlation with the aug-cc-pwCVnZ basis set ( $n=\mathrm{D}, \mathrm{T}, \mathrm{Q}$ and 5$)$. In order to accurately calculate the heats of formation, the following additional correction were included: scalar relativistic effects, atomic spin-orbit effects, and vibrational zero-point energies. For calibration purposes, the properties of some of the lithium compounds were predicted with iterative triple and quadruple excitations via CCSDT and CCSDTQ. The calculated geometry parameters, frequencies, heats of formation and bond dissociation energies (BDE) were compared with all available experimental measurements and are in excellent agreement with high quality experimental data. High level calculations are required to correctly predict that $\mathrm{K}_{2} \mathrm{O}$ is linear and that the ground state of $\mathrm{KO}$ is ${ }^{2} \Sigma^{+}$not ${ }^{2} \Pi$ as in $\mathrm{LiO}$ and $\mathrm{NaO}$. This reliable and consistent set of calculated thermodynamic data is appropriate for use in combustion and atmospheric simulations. This work was published in "Structures and Heats of Formation of Simple Alkali Metal Compounds: Hydrides, Chlorides, Fluorides, Hydroxides and Oxides for Li, Na and K,” 
M. Vasiliu, S. Li, K. A. Peterson, D. Feller, J. L. Gole, and D. A. Dixon, J. Phys. Chem. A, 2010, $114,4272-4281$

Geometry parameters, frequencies, heats of formation, and bond dissociation energies are predicted for the simple alkaline earth (Be, $\mathrm{Mg}$ and $\mathrm{Ca}$ ) fluorides, chlorides, oxides and hydroxides at the coupled cluster theory [CCSD(T)] level including core-valence correlation with the aug-cc-pwCVnZ basis sets up to $n=5$ in some cases. Additional corrections (scalar relativistic effects, vibrational zero-point energies, and atomic spin-orbit effects) were necessary to accurately calculate the total atomization energies and heats of formation. The calculated geometry parameters, frequencies, heats of formation, and bond dissociation energies were compared with the available experimental data. For a number of these alkaline earth compounds, the experimental geometries and energies are not reliable. $\mathrm{MgF}_{2}$ and $\mathrm{BeF}_{2}$ are predicted to be linear and $\mathrm{CaF}_{2}$ is predicted to be bent. $\mathrm{BeOH}$ is predicted to be bent, whereas $\mathrm{MgOH}$ and $\mathrm{CaOH}$ are linear. The $\mathrm{OBeO}$ angle in $\mathrm{Be}(\mathrm{OH})_{2}$ is not linear and the molecule has $C_{2}$ symmetry. The heat of formation at $298 \mathrm{~K}$ for $\mathrm{MgO}$ is calculated to be $32.3 \mathrm{kcal} / \mathrm{mol}$ and the bond dissociation energy at $0 \mathrm{~K}$ is predicted to be $61.5 \mathrm{kcal} / \mathrm{mol}$. These calculations provide benchmark data for our work on metal oxide clusters for reactions of water with models of mineral surfaces. This work was published in "Structures and Heats of Formation of Simple Alkaline Earth Metal Compounds: Fluorides, Chlorides, Oxides, and Hydroxides for Be, Mg, and Ca,” M. Vasiliu, S. Li, D. Feller, J. L. Gole, and D. A. Dixon, J. Phys. Chem. A, 2010, 114, 9349-9358

\section{Main group Chemistry: Arsenic, Selenium and Nitrogen Fluorine Chemistry}

There is substantial interest in the properties of compounds containing arsenic due to their roles as pollutants and to their use in a wide range of applications from pesticides to chemical vapor deposition (CVD) where they are involved in the synthesis and doping of semiconductor materials. For example, there are issues with the speciation of As compounds in the environment and the role of As compounds in well water, in addition to the controversial role of As in proteobacteria, which rely on arsenic instead of phosphorus. Structures, vibrational frequencies, atomization energies at $0 \mathrm{~K}$ and heats of formation at $0 \mathrm{~K}$ and $298 \mathrm{~K}$ are predicted for the compounds $\mathrm{As}_{2}, \mathrm{AsH}, \mathrm{AsH}_{2}, \mathrm{AsH}_{3}, \mathrm{AsF}, \mathrm{AsF}_{2}$, and $\mathrm{AsF}_{3}$ from frozen core coupled cluster theory calculations performed with large correlation-consistent basis sets, up through augmented sextuple zeta quality. The coupled cluster calculations involved up through quadruple excitations. For $\mathrm{As}_{2}$ and the hydrides, it was also possible to examine the impact of full configuration interaction on some of the properties. In addition, adjustments were incorporated to account for extrapolation to the frozen core complete basis set limit, core/valence correlation, scalar relativistic effects, the diagonal Born-Oppenheimer correction and atomic spin orbit corrections. Based on our best theoretical $\mathrm{D}_{0}\left(\mathrm{As}_{2}\right)$ and the experimental heat of formation of $\mathrm{As}_{2}$, we propose a revised $0 \mathrm{~K}$ arsenic atomic heat of formation of $68.86 \pm 0.8 \mathrm{kcal} / \mathrm{mol}$. While generally good agreement was found between theory and experiment, the heat of formation of $\mathrm{AsF}_{3}$ was an exception. Our best estimate is more than $7 \mathrm{kcal} / \mathrm{mol}$ more negative than the single available experimental value, which argues for a re-examination of that measurement. This work was published in "Thermodynamic Properties of Arsenic Compounds and the Heat of Formation of the As Atom from High Level Electronic Structure Calculations,” D. Feller, M. Vasiliu, D.J. Grant, and D. A. Dixon, J. Phys. Chem. A, 2011, 115, 14667-14676. 
Selenium is found in a number of minerals and plays a role in a number of technologies. Se is in the active site of the enzymes glutathione peroxidase and thioredoxin reductase and most animals require trace amount of Se. The bond dissociation energies (BDEs), fluoride and fluorocation affinities, and electron affinities of $\mathrm{SeF}_{n}(\mathrm{n}=1-6), \mathrm{SeOF}_{\mathrm{n}}(\mathrm{n}=0-4)$, and $\mathrm{SeO}_{2} \mathrm{~F}_{\mathrm{n}}(\mathrm{n}=0-2)$ have been predicted with coupled cluster $\operatorname{CCSD}(\mathrm{T})$ theory extrapolated to the complete basis set limit. To achieve near chemical accuracy, additional corrections were added to the complete basis set binding energies based on frozen core coupled cluster theory energies. These included corrections for core-valence effects, scalar relativistic effects, for first-order atomic spin-orbit effects, and vibrational zero point energies. The adiabatic BDEs contain contributions from product reorganization energies and, therefore, can be much smaller than the diabatic BDEs and can vary over a wide range. For thermochemical calculations, the adiabatic values must be used, whereas for bond strength and kinetic considerations, the diabatic values should be used when only small displacements of the atoms without change of the geometry of the molecule are involved. The adiabatic Se-F BDEs of $\mathrm{SeF}_{\mathrm{n}}(\mathrm{n}=1-6)$ are: $\mathrm{SeF}_{6}=90, \mathrm{SeF}_{5}=27, \mathrm{SeF}_{4}=93, \mathrm{SeF}_{3}=$ $61, \mathrm{SeF}_{2}=86$, and $\mathrm{SeF}=76 \mathrm{kcal} / \mathrm{mol}$, and the corresponding diabatic values are: $\mathrm{SeF}_{6}=90, \mathrm{SeF}_{5}$ $=88, \mathrm{SeF}_{4}=93, \mathrm{SeF}_{3}=74, \mathrm{SeF}_{2}=86$, and SeF $=76 \mathrm{kcal} / \mathrm{mol}$. The adiabatic Se-O BDEs of $\mathrm{SeO}_{\mathrm{n}}$ $(\mathrm{n}=1-3), \mathrm{SeOF}_{\mathrm{n}}(\mathrm{n}=1-4)$, and $\mathrm{SeO}_{2} \mathrm{~F}_{\mathrm{n}}(\mathrm{n}=1,2)$ range from 23 to $107 \mathrm{kcal} / \mathrm{mol}$, whereas the diabatic ones range from 62 to $154 \mathrm{kcal} / \mathrm{mol}$. The adiabatic Se-F BDEs of $\mathrm{SeOF}_{\mathrm{n}}(\mathrm{n}=1-4)$ and $\mathrm{SeO}_{2} \mathrm{~F}_{\mathrm{n}}$ $(\mathrm{n}=1,2)$ range from 20 to $88 \mathrm{kcal} / \mathrm{mol}$, whereas the diabatic ones range from 73 to $112 \mathrm{kcal} / \mathrm{mol}$. The fluoride affinities of $\mathrm{SeF}_{\mathrm{n}},(\mathrm{n}=1-6), \mathrm{SeO}_{\mathrm{n}},(\mathrm{n}=1-3), \mathrm{SeOF}_{\mathrm{n}},(\mathrm{n}=1-4)$, and $\mathrm{SeO}_{2} \mathrm{~F}_{\mathrm{n}}(\mathrm{n}=1,2)$ range from 15 to $121 \mathrm{kcal} / \mathrm{mol}$, demonstrating that the Lewis acidity of these species covers the spectrum from very weak $\left(\mathrm{SeF}_{6}\right)$ to very strong $\left(\mathrm{SeO}_{3}\right)$ acids. The electron affinities which are a measure of the oxidizing power of a species, span a wide range from $1.56 \mathrm{eV}$ in $\mathrm{SeF}_{4}$ to $5.16 \mathrm{eV}$ in $\mathrm{SeF}_{5}$ and for the free radicals are much higher than for the neutral molecules. Another interesting feature of these molecules and ions stems from the fact that many of them possess both a Se free valence electron pair and a free unpaired valence electron, raising the questions of their preferred location and their influence on the Se-F and $\mathrm{Se}=\mathrm{O}$ bond strengths. The NMR and vibrational spectra of $\mathrm{SeF}_{5}^{-}, \mathrm{SeOF}_{3}{ }^{-}$and $\mathrm{SeO}_{2} \mathrm{~F}^{-}$, and their assignments were re-examined and corrected by comparison with high level theoretical calculaions. Whereas the previously published normal coordinate analysis of $\mathrm{SeF}_{5}{ }^{-}$is correct, that for $\mathrm{SeOF}_{3}{ }^{-}$needed major revision. The pair-wise substitution of two fluorine atoms in $\mathrm{SeF}_{5}{ }^{-}$by a doubly bonded oxygen atom to make $\mathrm{SeF}_{3} \mathrm{O}^{-}$reduces the $\mathrm{CN}$ of Se from 6 to 4 , and the presence of a sterically active free valence electron pair on Se has a strong influence on the bonding of the fluorine ligands. This work was published in "Thermochemical Properties of Selenium Fluorides, Oxides and Oxofluorides,” V. E. Jackson, D. A. Dixon, and K. O. Christe, Inorg. Chem. 2012, 51, 24722485 and "Seleium(IV) Fluoride and Oxofluoride Anions," K. O. Christe, D. A. Dixon, R. Haiges, M. Hopfinger, Vi. E. Jackson, T. M. Klapötke, B. Krumm, and M. Scherr, J. Fluorine Chem. 2010, 131, 791-799

$\mathrm{N}_{2} \mathrm{~F}^{+}$salts are important precursors in the synthesis of the highly energetic $\mathrm{N}_{5}^{+}$compounds, and better methods were needed for their larger scale production. A new, marginally stable $\mathrm{N}_{2} \mathrm{~F}^{+}$salt, $\mathrm{N}_{2} \mathrm{~F}^{+} \mathrm{Sn}_{2} \mathrm{~F}_{9}{ }^{-}$, was prepared and characterized. An ordered crystal structure was obtained for $\mathrm{N}_{2} \mathrm{~F}^{+} \mathrm{Sb}_{2} \mathrm{~F}_{11}{ }^{-}$, resulting in the first observation of individual $\mathrm{N} \equiv \mathrm{N}$ and N-F bond distances for $\mathrm{N}_{2} \mathrm{~F}^{+}$in the solid phase. The observed $\mathrm{N} \equiv \mathrm{N}$ and $\mathrm{N}-\mathrm{F}$ bond distances of 1.089(9) and 1.257(8) $\AA$, respectively, are among the shortest experimentally observed N-N and N-F bonds. High-level electronic structure calculations at the $\operatorname{CCSD}(\mathrm{T})$ level with correlation-consistent basis sets 
extrapolated to the complete basis limit show that cis- $\mathrm{N}_{2} \mathrm{~F}_{2}$ is more stable than trans- $\mathrm{N}_{2} \mathrm{~F}_{2}$ by 1.4 $\mathrm{kcal} / \mathrm{mol}$ at $298 \mathrm{~K}$. The calculations also demonstrate that the lowest uncatalyzed pathway for the trans-cis isomerization of $\mathrm{N}_{2} \mathrm{~F}_{2}$ has a barrier of $60 \mathrm{kcal} / \mathrm{mol}$ and involves rotation about the $\mathrm{N}=\mathrm{N}$ double bond. This barrier is substantially higher than the energy required for the dissociation of $\mathrm{N}_{2} \mathrm{~F}_{2}$ to $\mathrm{N}_{2}$ and $2 \mathrm{~F}$. Therefore, some of the $\mathrm{N}_{2} \mathrm{~F}_{2}$ dissociates before undergoing an uncatalyzed isomerization, with some of the dissociation products probably catalyzing the isomerization. Furthermore, it is shown that the trans-cis isomerization of $\mathrm{N}_{2} \mathrm{~F}_{2}$ is catalyzed by strong Lewis acids, involves a planar transition state of symmetry $C_{\mathrm{s}}$, and yields a 9:1 equilibrium mixture of cis- $\mathrm{N}_{2} \mathrm{~F}_{2}$ and trans $-\mathrm{N}_{2} \mathrm{~F}_{2}$. The increased reactivity of cis- $\mathrm{N}_{2} \mathrm{~F}_{2}$ with Lewis acids and the exclusive formation of cis $-\mathrm{N}_{2} \mathrm{~F}_{2}$ in the reaction of $\mathrm{N}_{2} \mathrm{~F}^{+}$with $\mathrm{F}^{-}$can now be explained. The geometry and vibrational frequencies of the $\mathrm{F}_{2} \mathrm{~N}=\mathrm{N}$ isomer have also been calculated and imply strong contributions from ionic $\mathrm{N}_{2} \mathrm{~F}^{+} \mathrm{F}^{-}$resonance structures, similar to those in $\mathrm{F}_{3} \mathrm{NO}$ and FNO. This work was published as the cover article in "Dinitrogen Difluoride Chemistry. Improved Syntheses of cis- and trans- $\mathrm{N}_{2} \mathrm{~F}_{2}$, Synthesis and Characterization of $\mathrm{N}_{2} \mathrm{~F}^{+} \mathrm{Sn}_{2} \mathrm{~F}_{9}^{-}$, Ordered Crystal Structure of $\mathrm{N}_{2} \mathrm{~F}^{+} \mathrm{Sb}_{2} \mathrm{~F}_{11}$, High-Level Electronic Structure Calculations of cis $-\mathrm{N}_{2} \mathrm{~F}_{2}$, trans $-\mathrm{N}_{2} \mathrm{~F}_{2}, \mathrm{~F}_{2} \mathrm{~N}=\mathrm{N}$, and $\mathrm{N}_{2} \mathrm{~F}^{+}$, and Mechanism of the trans-cis Isomerization of $\mathrm{N}_{2} \mathrm{~F}_{2},{ }^{\prime} \mathrm{K}$. $\mathrm{O}$. Christe, D. A. Dixon, D. J. Grant, R. Haiges, F. S. Tham, A. Vij, V. Vij, T.-H. Wang, and W. W. Wilson, Inorg. Chem. 2010, 49, 6823.

\section{1,2,3-Trichloropropane - a groundwater contaminant}

1,2,3-Trichloropropane (TCP) occurs as an groundwater contaminant from agricultural use of fumigants that contain TCP as an impurity, cleaning/degreasing operations with solvent formulations containing TCP, and chemical manufacturing where TCP was a precursor, e.g., in the synthesis of epichlorhydrin. Recently, improved monitoring capabilities have lead to more frequent detection of TCP in groundwater samples, and reassessment of its toxicity has resulted in more stringent regulation. Together, these developments have placed TCP among the emerging contaminants that currently are being considered by a number of organizations as a possible priority for future research and regulation (e.g. U.S. Environmental Protection Agency). Electronic structure methods were used to calculate the gas-phase and aqueous phase reaction energies for reductive dechlorination (i.e. hydrogenolysis), reductive $\beta$-elimination, dehydrochlorination, and nucleophilic substitution by $\mathrm{OH}^{-}$of 1,2,3-trichloropropane. The thermochemical properties were calculated by using ab initio electronic structure calculations, isodesmic reactions schemes, gas-phase entropy estimates, and continuum solvation models for 1,2,3-trichloropropane and several likely degradation products: $\mathrm{CH}_{3} \mathrm{CHClCH}_{2} \mathrm{Cl}$, $\mathrm{CH}_{2} \mathrm{ClCH}_{2} \mathrm{CH}_{2} \mathrm{Cl}, \quad \cdot \mathrm{CH}_{2} \mathrm{CHClCH}_{2} \mathrm{Cl}, \quad \mathrm{CH}_{2} \mathrm{ClC} \cdot \mathrm{HCH}_{2} \mathrm{Cl}, \quad \mathrm{CH}_{2}=\mathrm{CCl}\left(\mathrm{CH}_{2} \mathrm{Cl}\right), \quad$ cis$\mathrm{CHCl}=\mathrm{CH}\left(\mathrm{CH}_{2} \mathrm{Cl}\right), \quad$ trans- $\mathrm{CHCl}=\mathrm{CH}\left(\mathrm{CH}_{2} \mathrm{Cl}\right), \quad \mathrm{CH}_{2}=\mathrm{CH}\left(\mathrm{CH}_{2} \mathrm{Cl}\right), \quad \mathrm{CH}_{2} \mathrm{ClCHClCH}_{2} \mathrm{OH}$, $\mathrm{CH}_{2} \mathrm{ClCH}(\mathrm{OH}) \mathrm{CH}_{2} \mathrm{Cl}, \mathrm{CH}_{2}=\mathrm{CCl}\left(\mathrm{CH}_{2} \mathrm{OH}\right), \mathrm{CH}_{2}=\mathrm{C}(\mathrm{OH})\left(\mathrm{CH}_{2} \mathrm{Cl}\right)$, and $\mathrm{CH}_{3} \mathrm{C}(=\mathrm{O}) \mathrm{CH}_{2} \mathrm{Cl}$. On the basis of these thermochemical estimates, together with a $\mathrm{Fe}(\mathrm{II}) / \mathrm{Fe}(\mathrm{III})$ chemical equilibrium model for natural reducing environments, all of the reactions studied were predicted be very favorable in the standard state and under a wide range of $\mathrm{pH}$ conditions. The most favorable reaction was reductive $\beta$-elimination $\left(\Delta \mathrm{G}_{\mathrm{rxn}}^{0} \approx-32 \mathrm{kcal} / \mathrm{mol}\right)$, followed closely by reductive dechlorination $\left(\Delta \mathrm{G}_{\text {rxn }}^{0} \approx-27 \mathrm{kcal} / \mathrm{mol}\right)$, dehydrochlorination $\left(\Delta \mathrm{G}_{\mathrm{rxn}}^{\mathrm{o}} \approx-27 \mathrm{kcal} / \mathrm{mol}\right)$, and nucleophilic substitution by $\mathrm{OH}^{-}\left(\Delta \mathrm{G}_{\mathrm{rxn}}^{0} \approx-25 \mathrm{kcal} / \mathrm{mol}\right)$. For both reduction reactions studied, it was found that the first electron-transfer step, yielding the intermediates $\cdot \mathrm{CH}_{2} \mathrm{CHClCH}_{2} \mathrm{Cl}$, and $\mathrm{CH}_{2} \mathrm{ClC} \cdot \mathrm{HCH}_{2} \mathrm{Cl}$, was not favorable in the standard state $\left(\Delta \mathrm{G}^{0}{ }_{\mathrm{rxn}} \approx+15 \mathrm{kcal} / \mathrm{mol}\right)$, and was 
predicted to occur only at relatively high $\mathrm{pH}$ values. This result suggests that reduction by natural attenuation is unlikely. The results of this study demonstrate that ab initio electronic structure methods can be used to calculate the reaction energetics of a potentially large number of organic compounds in solution, including radical and anionic compounds for which experimental data are unavailable, and can be used to help identify the potentially important environmental degradation reactions. This work was published in "Free Energies for Degradation Reactions of 1,2,3-Trichloro-Propane from ab initio Electronic Structure Theory,” E. J. Bylaska, K. R. Glaesemann, A. R. Felmy, M. Vasiliu, D. A. Dixon, and P. G. Tratnyek, J. Phys. Chem. A, 2010, 114, 12269-12282.

\section{Publications 2010-2013}

"Thermodynamic Properties of the $\mathrm{XO}_{2}, \mathrm{X}_{2} \mathrm{O}, \mathrm{XYO}, \mathrm{X}_{2} \mathrm{O}_{2}$, and $\mathrm{XYO}_{2}(\mathrm{X}, \mathrm{Y}=\mathrm{Cl}, \mathrm{Br}$ and $\mathrm{I})$ Isomers,” by Daniel J. Grant, Edward B. Garner III, Myrna H. Matus, Minh Tho Nguyen, Kirk A. Peterson, Joseph S. Francisco, and David A. Dixon, J. Phys. Chem. A, 2010, 114, 4254

"Structures and Heats of Formation of Simple Alkali Metal Compounds: Hydrides, Chlorides, Fluorides, Hydroxides and Oxides for Li, Na and K,” M. Vasiliu, S. Li, K. A. Peterson, D. Feller, J. L. Gole, and D. A. Dixon, J. Phys. Chem. A, 2010, 114, 4272.

"Structures and Heats of Formation of Simple Alkaline Earth Metal Compounds: Fluorides, Chlorides, Oxides, and Hydroxides for Be, Mg, and Ca,” M. Vasiliu, S. Li, D. Feller, J. L. Gole, and D. A. Dixon, J. Phys. Chem. A, 2010, 114, 9349-9358

“Seleium(IV) Fluoride and Oxofluoride Anions,” K. O. Christe, D. A. Dixon, R. Haiges, M. Hopfinger, Vi. E. Jackson, T. M. Klapötke, B. Krumm, and M. Scherr, J. Fluorine Chem. 2010, 131,791

"Dinitrogen Difluoride Chemistry. Improved Syntheses of cis- and trans- $\mathrm{N}_{2} \mathrm{~F}_{2}$, Synthesis and Characterization of $\mathrm{N}_{2} \mathrm{~F}^{+} \mathrm{Sn}_{2} \mathrm{~F}_{9}{ }^{-}$, Ordered Crystal Structure of $\mathrm{N}_{2} \mathrm{~F}^{+} \mathrm{Sb}_{2} \mathrm{~F}_{11}{ }^{-}$, High-Level Electronic Structure Calculations of cis- $\mathrm{N}_{2} \mathrm{~F}_{2}$, trans $-\mathrm{N}_{2} \mathrm{~F}_{2}, \mathrm{~F}_{2} \mathrm{~N}=\mathrm{N}$, and $\mathrm{N}_{2} \mathrm{~F}^{+}$, and Mechanism of the transcis Isomerization of $\mathrm{N}_{2} \mathrm{~F}_{2}$," K. O. Christe, D. A. Dixon, D. J. Grant, R. Haiges, F. S. Tham, A. Vij, V. Vij, T.-H. Wang, and W. W. Wilson, Inorg. Chem. 2010, 49, 6823.

"Free Energies for Degradation Reactions of 1,2,3-Trichloro-Propane from ab initio Electronic Structure Theory,” E. J. Bylaska, K. R. Glaesemann, A. R. Felmy, M. Vasiliu, D. A. Dixon, and P. G. Tratnyek, J. Phys. Chem. A, 2010, 114, 12269-12282.

"Thermodynamic Properties of Arsenic Compounds and the Heat of Formation of the As Atom from High Level Electronic Structure Calculations,” D. Feller, M. Vasiliu, D.J. Grant, and D. A. Dixon, J. Phys. Chem. A, 2011, 115, 14667-14676.

“Thermochemical Properties of Selenium Fluorides, Oxides and Oxofluorides,” V. E. Jackson, D. A. Dixon, and K. O. Christe, Inorg. Chem. 2012, 51, 2472-2485 
"Fundamental Thermochemical Properties of Amino Acids: Gas-Phase and Aqueous Acidities and Gas-Phase Heats of Formation,” M. L. Stover, V. E. Jackson, M. H. Matus, M. A. Adams, C. J. Cassady, and D. A. Dixon, J. Phys. Chem. B, 2012, 116, 2905-2916.

Density Functional Theory Study of the Complexation of the Uranyl Dication with Anionic Phosphate Ligands with and without Water Molecules, V.E. Jackson, K. E. Gutowski, and D. A. Dixon J. Phys. Chem. A, submitted, June 2013.

\section{Presentations}

D. A. Dixon, Invited Lecture \& co-organizer, DOE BES Earth Sciences Council workshop: Computational Geochemistry: Predicting Properties of the Mineral-Water Interface, Annapolis, MD, January 2010.

D. A. Dixon, Invited Lecture, Chemistry, University of Southern Mississippi, Hattiesburg, MS, February 2010

D. A. Dixon, Invited Lecture, Center for Computational Sciences, University of Kentucky, Lexington, KY, February 2010

D. A. Dixon, Invited Lecture, Chemistry, Washington State University, Pullman WA, March 2010

D. A. Dixon, Invited Lecture, ACS National Meeting, Division of Geochemistry Symposium: Predicting Molecular Properties at the Mineral-Water Interface: Challenges and Opportunities for High Performance Computing, San Francisco, March 2010.

D. A. Dixon, Invited lecture, Chemistry, Union University, Jackson TN, April 2010.

V. E. Jackson, J. R. Duke, D. A. Dixon, Poster, Southeast Theoretical Chemistry Association (SETCA) Annual Meeting, Duke University, Durham, N.C., May 2010.

D. A. Dixon, Keynote Lecture, Goldschmidt 2010, in Section 18b, Elementary Reaction Mechanisms in Geochemistry, Knoxville TN, June 2010.

D. A. Dixon, Invited Lecture, PacifiChem 2010, Symposium on Fundamental and Applied Inorganic Fluorine Chemistry and Their Impacts on Energy Conservation and the Environment, Honolulu, HI, December. 2010.

D. A. Dixon, Invited Lecture, $20^{\text {th }}$ Winter Fluorine Conference, St. Petersburg Beach, FL, Jan. 2011.

D. A. Dixon, Invited Lecture, $241^{\text {st }}$ ACS National Meeting, Division of Computers in Chemistry: ACS Award for Computers in Chemical and Pharmaceutical Research Award: Symposium in Honor of Thom Dunning, Anaheim, CA, March 2011. 
D. A. Dixon, Invited Lecture, 2011 SETCA Annual Meeting, Mississippi State, Starksville MS May 13-14, 2011.

D. A. Dixon, Invited Lecture, Goldschmidt 2011, 19a: Radioactivity in the Environment: Damage, Solution, and Relativistic Effects, Prague, Aug 2011.

D. A. Dixon, Invited Lecture, $242^{\text {nd }}$ ACS National Meeting, Division of Fluorine Chemistry, Symposium in Honor of Donald J. Burton: "Fluorine Chemistry the Iowa Way" Denver , Aug. 2011.

D. A. Dixon, Invited Lecture, $243^{\text {rd }}$ ACS National Meeting, Division of Geochemistry, Computational Chemistry for Geochemistry, San Diego, March, 2012.

D. A. Dixon, Invited Lecture, $243^{\text {rd }}$ ACS National Meeting, Division of Nuclear Chemistry and Technology, A Career in Actinide Science: Tribute to Lester Morss, San Diego, March, 2012

D. A. Dixon, Invited Lecture, 2012 SETCA Annual Meeting, University of Georgia, Athens, GA, May 18-19, 2012. 